\title{
Repressalier mot kritiker i offentliga organisationer
}

\section{ULLA-CARIN HEDIN \& SVEN-AXEL MÅNSSON}

\begin{abstract}
I USA och andra anglosaxiska länder har en omfattande forskning kring fenomenet "whistleblowing" vuxit fram. Begreppet syftar på när anställda för fram kritik mot företeelser på sin arbetsplats t. ex. avslöjar interna missförhållanden som slarv i behandling av patienter/klienter, felaktiga produkter, maktövergrepp eller korruption. I Sverige har sådana studier hittills varit sällsynta. I denna artikel redovisas resultaten frän en nyligen genomförd studie av kritikerprocesser och konflikter kring kritiker inom svenska human service organisationer som socialtjänsten, skolan och sjukvairden.
\end{abstract}

Inom den offentliga arbetsmarknaden finns en lagstadgad rätt för arbetstagare att påtala missförhållanden och uttala kritik beträffande verksamheten, utförandet av tjänsterna eller behandlingen av medbor-

Ulla-Carin Hedin docent i socialt arbete vid institutionen för socialt arbete, Göteborgs universitet Sven-Axel Månsson, professor i socialt arbete vid Hälsa och samhälle, Malmö högskola garna. ${ }^{1}$ I vissa delar av den offentliga verksamheten har rätten att påtala missförhållanden också förstärkts genom särskilda paragrafer, t.ex. inom socialtjänstlagen

1 Yttrandefriheten för offentliga tjänstemän är grundlagsskyddad i regeringsformen (1974) yttrandefrihetsgrundlagen (1991:1469) och tryckfrihetsförordningen (1949:105) (www. regeringen.se). 
och hälso- och sjukvårdslagen. Yttrandefriheten i detta avseende betraktas som central för demokratin och ett kännemärke för den svenska välfärdsmodellen (Lundquist 2001). Samtidigt förekommer uppgifter om att tystnaden på arbetsplatserna har ökat på senare år och att det finns en rädsla att påtala missförhållanden och gå ut med kritik på sin arbetsplats (Brink et al. 2007). Man fruktar negativa reaktioner från arbetsledning eller arbetskamrater. Den ökade tystnaden och dess orsaker har undersökts i några studier ( t.ex. Aronsson \& Gustafsson 1999).

Hur utnyttjas då rätten att påtala missförhållanden inom offentliga organisationer? Och vad händer när man använder sig av denna rätt? Detta är frågor som vi har studerat i en kvalitativ studie, kallad Konflikter kring kritiker inom människovårdande organisationer - orsaker, förlopp och konsekvenser. Studien genomfördes under åren 2003-07 med stöd från Forskningsrådet för arbetsliv och socialvetenskap. Syftet med denna artikel är att lyfta fram några intressanta resultat från studien, som gäller kritikerprocessens förlopp och konsekvenser samt diskutera dessa ur olika perspektiv. Grundfrågor är: Finns det risk för repressalier och utstötning från arbetsorganisationen som konsekvens av kritik? Och vilka faktorer medverkar i så fall till detta förlopp?

Vår studie handlar om s.k. whistleblowing inom svenska människovårdande organisationer som socialtjänsten, skolan och sjukvården. Ordet avser främst själva handlingen, att höja rösten och säga ifrån. En ofta använd definition har formulerats av Marcia Miceli och Janet Near, organisationspsykologer som studerat företeelsen inom en rad yrken i USA. De definierar whistleblowing som "när (tidigare eller nuvarande) organisationsmedlemmar avslöjar en illegal, omoralisk eller illegitim praktik, som arbetsgivarna kontrollerar, för personer eller organisationer som kanske kan påverka handlandet" (Miceli \& Near 1992 s. 15). Det innebär att den anställde inte bara är allmänt kritisk utan verkligen avslöjar ett missförhållande, som inte tidigare varit känt för personer som har makt att göra något åt saken. Andra forskare har lagt vikt vid handlingens karaktär av moralisk protest, t.ex. sociologen James Jasper (1997). Han menar att det fordras stark moralisk övertygelse för att våga protestera mot rådande spelregler, stå upp mot överlägsna krafter och kanske riskera vedergällning. Följaktligen använder han beteckningen "ethical resisters" (ungefär: etiska motståndsmän) för dem som vågar agera i linje med sin övertygelse. ${ }^{2}$

På svenska talar man ibland om "visslare" (Lundquist 2001). Men vi har valt att benämna dessa personer kritiker, vilket vi uppfattar som ett bättre begrepp. Kritikerprocessen innefattar själva protesthandlingen men också det fortsatta förloppet under vilket personen driver protesten ensam eller tillsammans med andra och möter olika slags reaktioner.

\section{Tidigare forskning}

Den svenska forskningen om kritikerpro-

2 Uttrycket kommer från Glazer \& Glazers numera klassiska studie från 1989: The whist leblowers: Exposing corruption in government and industry. 
cesser är sparsam. Någon enstaka studie kring offentliga ämbetsmäns yttrandefrihet och lagstadgade rätt att kritisera missförhållanden har genomförts (Lundquist 2001). I huvudsak har fenomenet studerats som en del av andra problemfält, t.ex. mobbning på arbetsplatser, grupprocesser och konflikter inom människovårdande organisationer (Ekeland 2006, Jordan 2002, Lennéer Axelson \& Thylefors 2005).

Den amerikanska forskningen på området är däremot omfattande. En av pionjärerna på området är Harvardprofessorn Albert Hirschman, som redan på 1970talet diskuterade olika handlingsalternativ när man som anställd observerar fel och brister i den egna organisationens verksamhet. Han kallade protest och kritik för voice, ge röst åt sitt missnöje, och ställde detta mot andra handlingsalternativ, som exit (att lämna organisationen) eller loyalty (att stillatigande och lojalt arbeta vidare) (Hirschman 1970). År 1972 kom en debattbok i USA, i vilken kända whistleblowers beskrev sina erfarenheter av kritikerprocesser i såväl privata företag som offentliga organisationer (Nader et al. 1972). Under 1970- och 80-talen initierades en rad studier av fenomenet whistleblowing inom olika samhällsvetenskapliga discipliner i USA. I huvudsak har forskarna studerat tre problemställningar:

Den första gäller vilka förhållanden i en organisation som leder till beslut att framföra kritik, och vilka i personalen som blir kritiker. Studier visar att det ofta rör sig om allvarliga problem som kritikerna reagerar på. Kritiken framförs av personer som är starkt engagerade och känner moraliskt ansvar för verksamheten (Miceli \& Near
1992, Rehg et al. 2004). Det är vanligtvis erfarna, välutbildade och kompetenta medarbetare med förtroendekapital och en stark ställning i organisationen som blir kritiker (Miceli \& Near 1992). De är också oftast personligen berörda av problemen och vill ändra på förhållandena (King 1999).

En annan problemställning handlar om själva kritikerhandlingen: Hur framförs kritiken, och till vem? Vad väcker handlingen för reaktioner inom och utom arbetsorganisationen? Ofta utmanas etablerade auktoritetsförhållanden inom organisationen av kritiken. Det kan finnas personer inom organisationen som gärna vill dölja problemen, t.ex. personer som tjänar på att missförhållandena består eller arbetsledare som är ansvariga för den kritiserade verksamheten (Near \& Miceli 1995). Inom ledningen vill man inte heller att organisationen skall förlora i anseende eller legitimitet. Att förmedla kritik externt är därför mer känsligt och ger starkare reaktioner än att framföra den internt (Mesmer-Magnus \& Viswesvaran 2005, Miceli \& Near 1992, Rehg et al. 2004).

Den tredje problemställningen gäller kritikens effektivitet och konsekvenser. Vad blir resultatet av kritiken? Vidtar man åtgärder för att förändra de förhållanden som har kritiserats? Och hur går det för dem som har framfört kritiken? Forskning visar att det ofta inte finns något samband mellan huruvida missförhållandena åtgärdas och vad som sker med kritikern. En organisation kan mycket väl ta fasta på kritiken och stoppa missförhållandena men ändå låta kritikern vidkännas repressalier för sitt brott mot organisationens norm- 
system (Mesmer-Magnus \& Viswesvaran 2005, Miceli \& Near 1992, Near \& Miceli 1995, Rehg et al. 2004).

Forskarna började tidigt granska konsekvenser av kritik och fann att många utsattes för repressalier till följd av sina avslöjanden (Miceli \& Near 1992). Repressalierna tog ofta formen av en upptrappad process (O’Day 1974). I det första stadiet av denna process försöker man påverka kritikern att ta tillbaka sin kritik eller att i alla fall inte gå vidare med den. Om kritikern inte faller till föga, går processen vidare till andra stadiet, då han eller hon blir isolerad inom organisationen. Isoleringen kan ta sig rent fysiska uttryck eller vara av mer psykosocial art. I det tredje stadiet blir arbetstagaren utsatt för klander, skuldbeläggande eller svartmålning. Det är vanligt att rykten sprids om kritikern, vilka sägs delvis förklara handlingssättet. Detta kan leda till att personen tystnar men också till att konflikten trappas upp. Under det andra eller tredje stadiet är det också vanligt att kritikerns arbetssituation förändras. Denne får andra arbetsuppgifter eller sämre arbetsförhållanden än tidigare. Det tredje stadiet kan följas av ett fjärde, där arbetstagaren blir utesluten och måste lämna organisationen, avskedas. Repressalierna behöver dock inte gå igenom alla stadierna utan kan upphöra efter en tid. Kritikern kan även välja att lämna organisationen medan processen pågår (O’Day, ibid.) I andra studier har man visat att hur repressalierna utvecklas har samband med kritikern som person, såväl som med situationen kring missförhållandena och med organisationens struktur och kultur (Mesmer-Magnus \& Viswesvaran 2005, Miceli \& Near 1994, Near \& Miceli 1995).

\section{Metoder och material}

Eftersom whistleblowing är föga utforskat i Sverige valde vi att göra en kvalitativ studie för att identifiera fenomenets egenskaper och variationer. Vi har gjort en fallstudie, där varje fall består av de handlingar och situationer som uppstått i och med att en eller flera arbetstagare har fört fram kritik, som avser olika slag av missförhållanden inom arbetsorganisationen eller brister i servicen till brukarna. Totalt har vi studerat 21 sådana fall.

Två urvalsprinciper har använts, nämligen maximal variation och intensitet $i$ urval (Miles \& Huberman 1994, Esaisson et al. 2004). Fallen har rekryterats via olika kontaktvägar. Hälften av kritikerfallen har vi fått kännedom om via olika fackförbund (11 fall), resten via media (4 fall) eller våra egna kollegiala nätverk ( 6 fall). Inom fackförbunden har man god kännedom om medlemmar som har behövt facklig hjälp på grund av kritik och konflikter på arbetsplatsen. De fackliga ombudsmännen tillfrågade medlemmar som de företrätt, om dessa kunde tänka sig att delta. Rekrytering via media innebar ett omfattande sökande i olika databaser och större svårigheter att få fram adressuppgifter och förfrågningar om medverkan. När vi hade arbetat en tid med datainsamlingen, spreds information om studien i våra kollegiala nätverk i socialt arbete. Arbetskamrater gav oss förslag på lämpliga personer att intervjua. När det rörde sig om personer som befann sig mitt i en pågående konflikt, avstod vi dock från kontakt. Utifrån etiska överväganden strävade vi efter att endast studera fall som „kallnat", där informanter eller andra per- 
soner inte kunde skadas av materialinsamlingen.

Totalt 28 personer (kritiker) har intervjuats, vilket betyder att mer än en person intervjuats i några av de totalt 21 fallen. Dessa kommer från socialtjänsten, sjukvården, skolan eller svenska kyrkan. ${ }^{3}$ Vissa faktauppgifter om kritikerna har sammanställts t.ex. kön, ålder, utbildning och tjänsteställning. Av de intervjuade är 18 kvinnor och 10 män. Det finns tio arbetsledare bland informanterna, de flesta av dessa är s.k. första linjens chefer som befinner sig nära verksamheten. De flesta är i åldern 40-60 år och de har genomgående långa anställningstider (mer än 10 år) inom arbetsorganisationen ifråga. Mer än hälften av dem har någon form av akademisk utbildning i grunden.

Intervjuerna med kritikerna genomfördes under tiden 2004-2006. De har varierat i längd mellan två och fem timmar och genomförts med hjälp av en intervjuguide med vissa frågeteman, som brukligt är. Inledningsvis ställdes frågor om de förhållanden som givit upphov till kritiken. Sedan följde en genomgång av förloppet: när och hur man framförde kritiken, vad den innehöll, vem som tog emot den och vilka reaktioner som uppkom inom och utom arbetsorganisationen. Vi ställde också frågor om konsekvenserna på kort och lång sikt för dem själva och för andra inblandade, om förekomsten av socialt stöd samt om hur informanten värderat utfallet av kritiken »i backspegeln«. Sist kom frågor om nuläget,

3 Undersökningsperioden omfattar åren 19952004. Fram till år 2000 var svenska kyrkan en offentlig organisation. huruvida konflikten var löst eller levde kvar i någon form i organisationen samt vilka lärdomar som informanten hade dragit av hela förloppet. Varje intervju bandades och skrevs ut i sin helhet.

Kritikerintervjuerna kompletterades med 30 intervjuer med s.k. nyckelpersoner på arbetsplatserna, t.ex. fackliga ombudsmän och arbetskamrater, som hade följt kritikerprocessen på nära håll och väl kände till händelseförloppet. Förutom intervjuer består materialet av en mängd dokument, huvudsakligen av tre slag: kritikerns eget material av typen brev och skrivelser, offentligt myndighetsmaterial samt artiklar och inslag i media. Särskilt myndighetsmaterialet, såsom utredningar, yttranden och beslut i sakfrågan, har kompletterat kritikernas berättelser och gett en mer allsidig bild av fallen.

Materialet har sammanfattats och analyserats ur tre olika perspektiv. Det har känts naturligt för oss att analysera intervjupersonernas berättelser ur ett interaktionistiskt perspektiv, som vi tidigare tillämpat på andra material (Hedin \& Månsson 1998). Vilka har varit de främsta aktörerna i konflikten? Hur har olika handlingar inverkat på samspelet? Kan man se några tydliga faser eller vändpunkter i förloppet? Vilka konsekvenser eller förändringar har det medfört? Vi har även försökt analysera materialet ur ett arbetsmiljöperspektiv, där begrepp som stressorer, krav, konflikter och socialt stöd har använts (Karasek \& Theorell 1990, Währborg 2002). Hit hör också en undersökning av vilket socialt stöd som kritikerna har fått från sitt personliga nätverk under olika faser av kritikerprocessen (Vaux 1988, Burleson et al.1994). Slutligen har 
ett organisationsteoretiskt perspektiv varit nödvändigt vid analysen, då omorganisationer, förändrad arbetsledning, nya arbetsmetoder och etiska dilemman i förhållande till klienter/brukare är bakgrunden till många kritikerkonflikter (Hasenfeld 1983). Kraven på flexiblitet och anpassning i det människovårdande arbetet har ökat (Allvin et al. 2006). Människovårdens specifika karaktär (Hasenfeld 1992) har inte alltid beaktats vid organisationsförändringar, vilket lett till problem och dilemman för personalen (Pettersson et al. 2006).

\section{Kritikerprocessens förlopp}

Vi redovisar våra resultat beträffande kritikerprocessens första faser mer översiktligt. Därefter fördjupar vi oss i de senare faserna av förloppet, där vi funnit att det föreligger en risk för repressalier och utsortering från arbetsorganisationen.

\section{Anledningartill kritik}

I intervjumaterialet kan vi urskilja sex olika typer av missförhållanden, som personal har reagerat på och som lett till kritik. Det handlar om (1) nedskärningar eller omorganisationer av verksamheter, som medfört problem eller nackdelar för brukare. Här förekommer "välfärdsbrister" som t.ex. undermålig omsorg för äldre på äldreboenden eller bristande insatser till barn och ungdomar i förortsskolor. Det gäller även (2) införande av nya arbetsmetoder eller arbetssätt, som anses inadekvata eller etiskt olämpliga, och (3) nedtystande eller censur av rapporter om sociala problem som varit avsedda att publiceras offentligt. Samtliga dessa tre typer av missförhållanden gäller utsatta grupper av medborgare, vilkas situation har försämrats genom organisationens agerande. Men kritik har också utlösts av missförhållanden inne i organisationen, vilka påverkat personalens relationer och arbetsmiljö, såsom (4) ekonomiska oegentligheter, (5) diskriminering och kränkande särbehandling av viss personal på grund av kön eller sexuell läggning samt (6) bristande arbetsledning och dålig arbetsmiljö av mer allvarlig art.

Det förefaller som om brister ofta har förelegat under lång tid, innan de blir påtalade genom kritik. Förutom varaktigheten framstår missförhållandenas synlighet och allvarlighetsgrad som viktiga aspekter när kritikens trovärdighet $i$ senare faser bedöms av olika personer inom och utanför arbetsorganisationen (King 1997, Miceli \& Near 1992, Near \& Miceli 1995, Near et al. 2004).

\section{Beslut att gå ut med kritik}

I vårt material förefaller det vara personer med lång yrkeserfarenhet och god kompetens som påtar sig rollen som kritiker i arbetsgruppen (se även Miceli \& Near 1992). Ganska många av informanterna var vad som i den amerikanska forskningen kallas för "whistleblowers by role prescription", dvs. personer i vars arbetsuppgifter det ingår att lämna kritik (t.ex. revisorer eller skyddsombud) (ibid.). Tio personer var arbetsledare och sju personer hade fackliga eller politiska uppdrag, dvs. en majoritet av 
de intervjuade kritikerna hade stort ansvar i tjänsten.

De intervjuade kritikerna har sällan tagit beslutet att gå ut med kritik ensamma. De flesta har haft stöd av meningsfränder bland arbetskamraterna och kollegor. Omfattande diskussioner i arbetsgruppen har föregått beslutet. Bara några få informanter beskriver att de har beslutat sig utan att först ha rådgjort med kollegor. Av berättelserna förefaller det som om arbetsledare och andra i organisationen inte har sett (eller kanske inte velat se) det stöd för kritiken som har funnits inom organisationen. Istället kommer frågan om kritikerns personliga motiv för kritik nästan alltid upp under senare faser i processen, varvid lojalitetsfrågan blir central (Miceli \& Near 1992).

I många fall kan man se situationsfaktorer som ligger bakom beslutet att gå ut med kritik. Missförhållandena har t.ex. utvecklats till en nivå, där det framstår som nödvändigt att göra något åt dem. Framför allt verkar graden av handlingsutrymme spela stor roll (Handler 1992). Personer med någorlunda stort handlingsutrymme använder sig av detta för att åtgärda brister och problem i verksamheten. Flera intervjuade påpekar att de var naiva när de fattade beslutet att gå ut med kritik och inte hade en tanke på vilka reaktioner som de skulle möta. De handlade så att säga »i god tro« och ville åtgärda problem som fanns i verksamheten. Här framträder tydligt en kollision mellan kritikernas ambitioner och syften och hur kritiken kom att uppfattas av arbetsledare och andra i organisationen. Två helt olika perspektiv på händelseförloppet växer fram.

\section{Kritiken framförs}

Den tredje fasen i kritikerförloppet handlar om kritikens framförande. Intern kritik, t.ex. att informera arbetsledare om problem i verksamheten, anses ofta berättigad. Vi kan se att muntlig kritik och skriftlig kritik behandlas på olika sätt. Muntlig kritik kan diskuteras i organisationen och leda till förbättringar av verksamheten. Skriftlig kritik i rapporter, utredningar eller skrivelser innebär däremot risker för en alltför öppen exponering av brister och problem i verksamheten och behandlas därför annorlunda. I en fjärdedel av fallen har kritikerna stannat vid att framföra kritiken internt och inte gått vidare med den utanför organisationens gränser. I något fall har arbetsledare lovat att utreda frågan och kritikern har nöjt sig med detta. I ett par andra fall har personen kunnat förutse negativa reaktioner på ytterligare kritik och därför beslutat sig för att inte gå vidare.

I tre fjärdedelar av fallen har kritikerna efter en tids väntan på agerande från arbetsledningens sida gått vidare med kritiken externt, till mottagare utanför organisationen. Den vanligaste formen är här anmälningar om missförhållanden till någon tillsynsmyndighet, t.ex. JO. Härigenom blir problem och brister föremål för utredning, och det finns i dessa fall en omfattande dokumentation, som vi har kunnat ta del av. Anmälningarna leder ofta också till att missförhållandena kommer till allmänhetens kännedom genom medias bevakning och rapportering. Utredningar och rapporter där organisationens verksamhet genomlyses och problemen beskrivs är ett annat sätt att gå ut med kritik. Artik- 
lar i lokalpressen och reportage i radio och TV är ytterligare vägar att föra ut kritik till allmänheten. $\mathrm{Nu}$ får kritiken en offentlig karaktär och organisationen och arbetsledningen sätts under press. Ledningen måste börja utreda förhållandena och diskutera insatser för att förändra situationen. Det förefaller också som om kritik som framförs externt polariserar konflikten mellan olika grupper inne i organisationen. Många i arbetsledningen blir överraskade och kan känna sig orättvist anklagade. Efter intern kritik har man kanske börjat utreda och arbeta med brister och missförhållanden. $\mathrm{Nu}$ känner man sig orättvist beskylld och reagerar starkt. Den externa kritiken gör också att arbetsledningen "tappar ansiktet" vilket är ett effektivt sätt att trappa upp en konflikt (Jordan 2002).

\section{Reaktioner på kritiken}

Kritiken har i de undersökta fallen utlöst en mängd olikartade reaktioner från olika personer och grupper på arbetsplatsen. Ibland kommer också reaktioner från andra medborgare utanför arbetsorganisationen, såsom journalister och allmänhet. Informanterna har beskrivit stöd och positiva reaktioner från arbetskamrater, fackliga kollegor och från personer utanför arbetsorganisationen, både bekräftelse på kritiken (som uppfattas som riktig) och uttryck för respekt, gillande och stöd. En informant beskriver det stöd som hon fick av kollegorna i sin fackliga klubb, en annan att hon fick mycket stöd från allmänheten, vilket hon inte hade väntat sig. Ändå är det i informanternas berättelser de negativa reaktionerna som dominerar bilden. Det handlar om utskällningar, som de fått av arbetsledare, eller obehagliga möten med chefer och politiker, där förebråelser eller anklagelser har framförts. I några fall har kritikerna även blivit hotade av arbetsledare eller arbetskamrater. En informant beskriver exempelvis ett möte med arbetsledningen, där kritikergruppen anklagades för illojalitet mot organisationen. En annan intervjuperson berättar att hon en morgon, när hon kom till arbetet, blev hotad av sina kollegor. Det framgår tydligt av materialet att detta är kritikerprocessens mest dramatiska fas med många häftiga reaktioner.

Reaktionerna handlar om kritikens innehåll, att man inte delar den bild av verksamhetens brister som kritikerna har fört fram. Många gånger tycks också kritikens form uppröra arbetsledare och kamrater. Detta gäller framför allt artiklar och inslag i media, där reporterns sätt att skildra eller vinkla kritiken har upprört. I många fall är det också själva handlingen att gå utanför den egna arbetsorganisationen och exponera dess problem och brister i en offentlig kritik som arbetsledare och kollegor blir upprörda över. Det tycks finnas starka normer i många organisationer att man skall vara lojal med organisationen och inte yppa "familjehemligheter" som handlar om problem och brister i verksamheten. Arbetsplatskulturen tycks vara präglad av ett normsystem, där lojalitet och tystnad är vanliga ingredienser (Alvesson 2001).

En intressant företeelse är den successiva förändringen av reaktionerna under denna fas. Alldeles efter kritikens framförande förekommer det en rad skilda 
reaktioner hos olika personer. Men efter en tid tycks dessa smälta samman till ett par olika tolkningar av kritiken. Det växer fram två dominerande perspektiv både på kritikens innehåll (sakfrågan) och på kritikerns person och handlande. Denna process är troligen både medveten och mer omedveten. Vissa inflytelserika personer i organisationen förefaller vara aktiva $i$ utformandet av den dominerande bilden. I vissa fall berättas om arbetsledare, som har försökt vara objektiva och utreda sakfrågan samt lugna ned känslorna på arbetsplatsen. I andra fall är det en mycket polariserad svartvit bild som framträder, vilket torde vara ett tecken på en upptrappad konflikt (Ekeland 2006, Jordan 2002). I det läget förekommer inte sällan en omfattande påverkan av kritikerns arbetsgrupp och närstående i organisationen. Kritikerna beskriver hur kamrater som tidigare stödde deras sak, har lämnat dem och gått över till det dominerande lägret på arbetsplatsen.

\section{Konsekvenser av kritik}

Innan vi går in på de personliga följderna av kritiken i form av repressalier måste vi påpeka att de organisatoriska konsekvenserna av kritiken ofta är omfattande. I intervjumaterialet syns tre olika "reaktionssätt" i organisationen. I vissa organisationer har man tagit fasta på kritiken och genomfört omfattande förändringar av den kritiserade verksamheten. Detta mönster syns i ca en tredjedel av fallen i materialet. Så åstadkom t. ex. ett socialkontor omfattande personalförstärkningar, nyanställde handledare och genomförde stora utbildningsinsatser bland personalen, medan en anmälan om missförhållanden utreddes hos en tillsynsmyndighet. I några andra fall ledde kritiken till omfattande omorganisationer eller förändringar av arbetssätt och arbetsmetoder. Kritikerna nådde därmed sitt syfte med kritiken. Men det förekommer också exempel på att nya arbetsmetoder eller organisationsförändringar har stoppats genom personalens motstånd och kritikernas agerande.

I andra organisationer har man vidtagit mer begränsade åtgärder till följd av kritiken, t.ex. ändrat arbetsrutiner för en viss typ av ärenden eller genomfört utbildningsinsatser för att ändra personalens attityder. Vid en sjukhusklinik där det förekom diskriminerande attityder och yttranden av manliga läkare mot kvinnliga kollegor genomfördes ett utbildningsprogram om jämställdhet. Konsekvenserna av dessa mer begränsade åtgärder framgår inte tydligt i materialet. I ett litet antal fall förefaller kritiken inte ha lett till några åtgärder eller förändringar inom organisationen ifråga. De intervjuade menar att deras kritik inte har tagits på allvar eller fått några effekter på de missförhållanden som de påtalat och som bestått oförändrade (jfr Hedin et al. kommande).

I vissa fall förefaller kritiken således ha varit effektiv och lett till åsyftade förändringar. I andra fall framstår den som mindre framgångsrik. Dessa olika organisatoriska konsekvenser av kritiken bör man ha i minnet när man läser beskrivningar av de personliga repressalier som kritikerna har fått erfara.

Det förefaller inte finnas något tydligt 
mönster beträffande förhållandet mellan organisatoriska respektive personliga konsekvenser av kritik, något som också diskuterats av de amerikanska forskarna (Miceli \& Near 1992, Rehg et al. 2004, MesmerMagnus \& Viswesvaran 2005). I en organisation kan man mycket väl ta fasta på kritiken och genomföra omfattande åtgärder för att förbättra en verksamhet eller ett arbetssätt men ändå reagera med repressalier mot de personer, som framfört kritiken. I många organisationer förefaller det finnas olika normsystem: ett som handlar om sakförhållanden och verksamhet och ett annat som gäller personalens lojalitet och handlingar. Detta skulle kunna förklara de skilda reaktionsmönstren beträffande sak respektive person.

Bestraffningarna av kritikerna förefaller vara medvetna och planerade handlingar i syfte att tysta kritikerna och rädda organisationens anseende. De har en tydlig karaktär av strategiskt handlande, där organisationens intressen och den symboliska makten står i centrum (Hallett 2003).

\section{Olika typer av repressalier}

Bland våra fall kan urskiljas två undergrupper med avseende på kritikens konsekvenser för dem som förmedlat den. Grupp A har inte mött några repressalier eller bara fått enstaka bestraffningar efter sin kritik. De har kunnat arbeta vidare med en ganska oförändrad arbetssituation. Grupp B har fått utstå flera typer av repressalier som i hög grad påverkat deras fortsatta arbetssituation. Efter en tid har dessa lett till omplacering till annan arbetsenhet eller avsked från organisationen. Mer än hälften av våra fall tillhör grupp B. ${ }^{4}$

Fyra kritiker har helt undgått repressalier. I två fall har kritiken riktats mot andra enheters verksamhet inom samma kommunala förvaltning. En lärare har t.ex. kritiserat handläggningen av ett ärende inom socialtjänsten och anmält detta till en granskningsmyndighet. Arbetsledningen i hennes skola stödde henne i denna kritik och de som drabbats av den är arbetsledare och personal på socialkontoret. I två andra fall har kritiken framförts av fackliga företrädare med stort stöd i sin fackliga organisation. Resultaten kan tyda på att repressalier handlar både om relationen mellan kritikerna och dem som blir kritiserade och om maktförhållanden inne i organisationen (Mesmer-Magnus \& Viswesvaran 2005, Miceli \& Near 1994).

I grupp A ingår också fem fall, där enstaka repressalier har förekommit. Men dessa har haft en diffus karaktär som gör att de är svåra för utomstående att observera och påtala. De har tagit formen av uteblivna förmåner eller sämre arbetsvillkor för kritikerna i jämförelse med kollegor på samma kompetensnivå. En läkare som kritiserat arbetsmiljön på sin klinik beskriver t.ex. hur han fått sämre löneutveckling och fler jourtjänstgöringar än sina kollegor. Han tolkar detta som bestraffningar efter kritik, och yttranden och kommentarer från arbetsledare stöder denna uppfattning. Som repressalier är de dock så pass diffusa

4 Denna höga andel kan bero på vårt specifika urval. Enligt andra forskare förekommer repressalier i 17-38 procent av fallen bland offentliganställda kritiker (Rehg et al. 2004). 
att det öppnar för många alternativa tolkningar kring orsakerna.

I grupp B är repressalierna tydliga och av flera olika slag. Som vi tidigare nämnt hävdar O’Day (1974) att repressalier ofta utvecklas i en process med flera stadier. I vårt intervjumaterial syns inga tydliga stadier. Snarare förefaller det som om repressalier kombinerats på olika sätt inom organisationerna beroende på vem de kommer från (arbetsledning eller arbetskamrater) och vilka medel för bestraffningar som stått till buds. Det är också tydligt att processen kan variera tidsmässigt. Vissa informanter beskriver ett snabbt och dramatiskt förlopp, andra ett mer utdraget. Ett exempel ur materialet får illustrera hur processen kan se ut.

På ett socialkontor ville arbetsledningen införa en ny arbetsmetod i vissa ärenden. Socionomerna på kontoret ansåg att metoden var etiskt tvivelaktig och protesterade. Några av dem sände en skrivelse till socialnämnden om detta, och det förekom också artiklar i lokalpressen i frågan. Författarna till skrivelsen blev senare inkallade till möte med arbetsledningen, som anklagade dem för illojalitet och samarbetssvårigheter. Arbetsledningens press på gruppen ledde till att övriga kollegor, som tidigare gett gruppen sitt oreserverade stöd, började dra sig undan och kritikerna isolerades. Efter ett par månader splittrades gruppen. En av medlemmarna blev uppsagd på grund av arbetsbrist och de övriga blev omplacerade till andra arbetsenheter i kommunen.

I exemplet handlar det om kritik som framförts externt, så att brister i verksamheten avslöjats och organisationens arbetsmetoder blivit föremål för offentlig diskus- sion. Kritikerna har haft ett omfattande stöd på den egna arbetsplatsen men även hos medborgare i allmänhet. Arbetsledares ställningstaganden och agerande i konflikten blev betydelsefulla, och den omdiskuterade arbetsmetoden infördes aldrig. Kritiken var således effektiv, då den ledde till oförändrad service för brukarna. Men som forskare tidigare påpekat är följderna av kritik ofta inkongruenta. Ledningen kan lyssna på kritiken och genomföra förändringar och förbättra kritiserade förhållanden. Ändå kan kritikerna utsättas för repressalier, då de anses ha handlat på ett illojalt sätt mot sin arbetsgivare. Sakfrågan och personfrågan bedöms på olika sätt av organisationens ledning (Miceli \& Near 1992, Near \& Miceli 1995).

\section{Omdefiniering och utsortering}

Medan repressalierna pågår, förefaller kritikerns status och ställning i organisationen förändras. Från att ha betraktats som en pålitlig och duktig medarbetare, som arbetsledning och kamrater har haft förtroende för, förändras han eller hon i organisationens ögon, till en annan person, som är besvärlig, inkompetent eller rent av farlig. Detta sker stegvis under repressaliefasen.

Kritikerna har också beskrivit hur det har fabricerats rykten om dem, som har florerat i organisationen. I vissa rykten har det funnits en kärna av sanning som allt eftersom laddats med våldsamma överdrifter. I andra fall har de varit helt grundlösa. På basis av dessa rykten har det skapats en ny bild av organisationens kritiker, där de tillskrivits 
en rad negativa egenskaper. Syftet med ryktesspridningen verkar vara att ge en annan förklaring, än de avslöjade missförhållandena, till varför kritikern kunnat handla på detta sätt. Inte sällan förklaras agerandet med personligt missnöje med exempelvis lönen eller ställningen i organisationen. Eller det hävdas att kritikern har svårigheter att sköta sitt arbete på ett tillfredsställande sätt och försöker dölja detta genom att anklaga andra och rikta kritik mot verksamheten. En vanlig förklaring är också att kritikern har privata problem, t.ex. psykiska problem eller familjeproblem som skulle påverka hans handlande. Miceli och Near (1992) visar att vissa schabloner regelmässigt dyker upp som standardförklaringar till kritikers agerande.

Många informanter i grupp B beskrev också hur de parallellt med ryktesspridningen isolerades alltmer. Arbetskamraterna drog sig undan från dem, troligen rädda för att själva uppfattas som kritiker. Isoleringen handlar både om fysiskt avstånd och om utebliven kommunikation. Tre informanter i en kritikergrupp berättar hur de fick sitta ensamma i kafferummet när arbetskamraterna plötsligt en dag bytte "fikaplats". En annan arbetsgrupp (med både kritiker och »lojala» medlemmar) flyttades till en avsides belägen arbetslokal, där det blev svårt att hålla kontakt med övriga inom förvaltningen. En tredje informant berättar om hur hon försökte hålla kontakt med gamla kamrater efter kritiken. De flesta undvek henne men någon samtyckte till att luncha med henne, förutsatt att de valde en plats där det var liten risk för att kollegor skulle se dem. Kamraten var rädd för att själv drabbas av sanktioner om de observerades tillsammans.
Jämsides med isoleringen inträdde andra förändringar i kritikernas arbetssituation såsom kontroll av arbetstider eller hur arbetsuppgifterna utförts. Informanterna beskriver hur de tidigare varit betrodda medarbetare med ganska stort handlingsutrymme i arbetet men efter kritiken blev noggrant kontrollerade. En läkare som gjort en anmälan till en tillsynsmyndighet redogör för hur man började kontrollera hennes sätt att sköta patientarbetet. En socialarbetare med "flextid" vid kontoret blev kontrollerad beträffande sitt sätt att sköta arbetstidsrapporteringen. En präst blev ombedd att lämna in statistikuppgifter beträffande olika typer av arbetsuppgifter osv. Kontrollerna är troligen ett tecken på att kritikern nu har förlorat i förtroende hos arbetsledningen. Man anser sig inte längre kunna lita på personen, vars handlingsutrymme därför begränsas. Det senare blir också följden av att resurser som kritikerna tidigare förfogade över eller blivit lovade har minskats eller dragits in. Ett par arbetsledare skildrar hur personalresurser vid enheten har minskats eller hur utlovad datautrustning har dragits in. Andra informanter beskriver hur medel till aktiviteter med brukare har skurits ned eller försvunnit helt, vilket drabbat både personal och brukare. Informanterna har tolkat detta som bestraffningar på grund av kritik, vilka är speciellt kännbara, då de drabbat andra (ej inblandade) personer.

Till sist har repressalierna utmynnat $i$ ett möte med arbetsledningen, där man har förklarat att den kritiske arbetstagaren inte är tillräckligt duglig eller kompetent att utföra sitt arbete, eller att han/hon har misskött sina arbetsuppgifter och därför 
inte längre har arbetsledningens förtroende. Hälften av våra intervjupersoner beskriver olika varianter av sådana samtal med arbetsledare. En socialsekretare fick höra att hon hade stora samarbetssvårigheter, vilket under en lång anställning aldrig tidigare påtalats. Två undersköterskor fick veta att de allvarligt misskött omvårdnaden om patienterna och därför måste omplaceras omedelbart. En arbetsledare fick veta att hon inte hade rätt kompetens för uppgifterna, trots att detta även diskuterats när hon anställdes tre år tidigare. Vissa arbetsledare har närmat sig denna punkt på ett mer formellt sätt och sagt att det inte längre finns lämpliga arbetsuppgifter, att det råder arbetsbrist i förvaltningen eller övertalighet bland personalen etc. Därefter har dessa samtal utmynnat i förslag om omplacering till annan arbetsenhet eller uppsägning (med avgångsvederlag). Informanterna beskriver hur deras självförtroende har urholkats av tidigare repressalier, varför de inte haft något att sätta emot vid dessa samtal. Vissa kände sig chockade och paralyserade, hade svårt att fatta vad som hänt. Andra accepterade omplaceringen eller avskedet som något oundvikligt.

Denna process med repressalier, isolering, kontroll och förändring av arbetsvillkor beskrivs i tolv av de 21 fallen. Omplacering eller avsked har blivit slutet på processen. Om det funnits en grupp av kritiker omfattar denna "utsortering" i vissa fall alla medlemmar, i andra fall bara arbetsledaren. Övriga i gruppen har då fått vidkännas olika repressalier men har fått arbeta kvar med restriktioner (olika typer av förhållningsorder har beskrivits.) I tre av de tolv fallen har kritikerna inte väntat på förslag om avsked; istället har de tagit saken i egna händer och sagt upp sig, innan processen har kommit till slutpunkten. Man har funnit situationen ohållbar och velat agera själv för att bryta det destruktiva förloppet.

Som vi har tolkat mönstret är detta en stigmatiserings- och marginaliseringsprocess som informanterna har beskrivit (Goffman 1990). De olika delarna i processen medverkar till en omdefiniering av kritikern och dennes status i organisationen. Slutpunkten $\mathrm{i}$ processen blir en utsortering från arbetet, då den anställde antingen finner det omöjligt att stanna kvar eller tvingas att lämna arbetsplatsen genom uppsägning och avsked. Denna process har skildrats i många olika sammanhang i samband med stigmatisering och utstötning av oönskade individer eller grupper från sociala eller samhälleliga arenor (Becker 2006, Elias \& Scotson 1999, Goffman 1990).

\section{Diskussion}

Resultaten av vår studie är oroande. De visar att det inte är ofarligt att gå ut med kritik och peka på problem och brister i verksamheter inom olika offentliga organisationer. Många av informanterna har drabbats av någon form av repressalier efter kritik. För ungefär hälften har detta i hög grad påverkat deras arbetssituation. Vi anser att man i dessa fall kan tala om en stigmatiserings- och marginaliseringsprocess, som i flera fall slutat i omplacering eller avsked från tjänsten. En slutsats av studien är alltså att offentlig kritik kan leda till repressalier och utstötning ur arbetsor- 
ganisationen. Detta är ingen nyhet, andra forskare har kommit fram till liknande slutsatser (Miceli \& Near 1992, 1994, MesmerMagnus \& Viswesvaran 2005). Vilka faktorer är det då som påverkar utfallet i denna process? Utifrån våra resultat kan vi skönja faktorer på tre olika nivåer: en individuell, en interpersonell och en organisatorisk nivå. Men vi vill framhålla att våra iakttagelser bygger på ett begränsat material och att vidare och mer fördjupade studier krävs för att fånga komplexiteten i förloppet.

Faktorer på individuell nivå har med kritikerns person och ställning i organisationen att göra, men också med vem som är ansvarig för de kritiserade förhållandena och blir utpekad av kritiken. I vår studie kan man t.ex. se att underordnad personal på basnivå i organisationen, liksom arbetsledare på mellannivå (första linjens chefer) har utsatts för kraftiga repressalier. Även annan forskning har visat att kritiska personer på underordnade poster i organisationen är mest utsatta, vilket sannolikt beror på att de anses mindre värda för organisationen, och på auktoritetsförhållanden i organisationen, som inte får ifrågasättas. Att arbetsledare som kritiserar missförhållanden inom sin egen organisation ofta utsätts för omfattande och hårda repressalier, torde handla om de normer om lojalitet och tystnad som tycks ingå $i$ arbetsledares psykologiska kontrakt. Men det beror troligen också på att deras kritik är speciellt hotande för ledningen (Miceli \& Near 1992, 1994, Mesmer-Magnus \& Viswesvaran 2005). Experter med hög kompetens har fått utstå mindre repressalier, vilket är intressant att notera

Kritikens innehåll, form och mottagare förefaller även spela roll för repressalierna. Kritik som uttrycks i anmälningar till tillsynsmyndigheter ger förhållandevis kraftiga reaktioner och kan senare medföra repressalier. Vad media skriver eller sänder har stor inverkan på förloppet. Vidare är kritik av undermålig service till medborgare eller oetiskt bemötande av utsatta brukare uppenbarligen speciellt känslig att förmedla. Man kan också tala om »kommunala minfält», politiskt laddade områden. Ett sådant kan vara organisationsförändringar, om vilka beslut redan är fattade och som är på väg att genomföras. Om kritiken landar i ett sådant fält, med en redan inflammerad diskussion, utlöses ofta häftiga reaktioner hos ansvariga politiker eller chefer. Risken för repressalier tycks också öka när kritiken berör sådana frågor.

Relationer på interpersonell nivå påverkar också processen. Det gäller stödmobilisering $i$ arbetsgruppen och arbetsledares agerande. Intervjupersoner beskriver hur de fått stort stöd av arbetskamrater vid beslut om och framförande av kritik. Men när arbetsledningen reagerat negativt och utsatt kritikern för repressalier har det sociala stödet minskat och stödgruppen splittrats. I senare faser har kritikerna huvudsakligen fått emotionellt och instrumentellt stöd från anhöriga och personer utanför arbetsorganisationen. Om det har funnits flera kritiker i arbetsgruppen har dessa försökt stödja varandra sinsemellan. Berättelserna visar att det sociala stödet är kontextberoende (se Vaux 1988). Stödmobilisering i ett arbetsplatsnätverk påverkas av vilka problem som behöver lösas, hur relationerna är utformade och vilka normer kring stöd och hjälp som finns (Burleson 
et al.1994). Arbetsledningen kan genom sin hållning blockera möjligheterna att ge och få stöd. Våra resultat tyder t.ex. på att normsändare med inflytande i nätverket ganska effektivt kan blockera stöd till utsatta medlemmar. Andra forskare har visat att arbetsledare på mellannivå i organisationer kan utdela egna bestraffningar (utan ledningens stöd) om de upplever att deras auktoritet hotas (Wolfe Morrison \& Milleken 2000).

I vårt material kan man se att de närmaste arbetsledarna har haft stort inflytande på kritikerprocessernas utfall. Vissa har genom hotelser, ryktesspridning och kontrollåtgärder medverkat till att konflikten eskalerat, medan andra har försökt medla och förhandla med ledningen. Vi har också sett att arbetsledare genom dialog med kritikerna kan avbryta ett destruktivt förlopp på ett tidigt stadium. De kan också hindra bestraffningar eller i varje fall mildra dem. I ett par fall har repressalieförloppet avbrutits när gruppen har fått en ny arbetsledare, som har gått in och försökt stoppa konflikten. Arbetsledares inflytande på detta område är en intressant fråga för fördjupade studier.

Olika organisatoriska faktorer inverkar tydligt på kritikerprocessen. Vi vet att organisationers uppbyggnad och struktur påverkar kommunikationsflödet, och att hierarkiska organisationer med byråkratiska drag har svårare att hantera kritik därför att man är ovan att kommunicera med underställda och ta emot synpunkter från lägre nivåer i organisationen. Nästan all information går där uppifrån och ner och synpunkter $\mathrm{i}$ motsatt riktning är ovanliga. Ett mönster av »organizational silence» kan vara väl etable- rat inom organisationen (Wolfe Morrison \& Milleken 2000). Organisationsledningen spelar stor roll, både reellt och symboliskt, när det gäller att etablera normer och regler kring kommunikation och kritik (ibid.). I andra typer av organisationsstrukturer än de hierarkiska tycks det finnas ett jämförelsevis större utrymme för dialog och hantering av kritik (King 1999).

I vårt material har ledningarna reagerat med tystnad på den interna kritiken och därmed signalerat att den är ogiltig eller inte värd att diskutera. Kritikerna har väntat en tid på svar och sedan gått vidare till tillsynsmyndigheter eller media. Ur den synpunkten är tystnadens försvarsstrategi inte framgångsrik i längden. Oviljan att diskutera kritiska synpunkter kan också medföra att kompetenta och kreativa medarbetare väljer att lämna organisationen (Hirschman 1970). Eller att medarbetarnas engagemang i arbetet minskar med lägre arbetsprestationer som följd.

En annan betydelsefull faktor är organisationens legitimitet. Ledningens åtgärder i samband med kritik syftar ofta till att försvara anseendet och att upprätthålla bilden av verksamheten som effektiv, välorganiserad och serviceinriktad. Kritiken uppfattas som en attack mot den bilden. Detta är särskilt tydligt när kritiken har handlat om "välfärdsbrister", om att utsatta grupper inte får den vård och service de är berättigade till eller om att dåliga arbetsmetoder leder till oetiskt bemötande.

Verksamheten är finansierad med skattemedel, reglerad genom lagstiftning och drivs med professionell och kompetent personal. Olika medborgerliga intressegrupper kräver effektiv service av god kva- 
litet. De människovårdande organisationerna är således beroende av sitt anseende för att få brukare (klienter) till verksamheten, för att kunna anställa kvalificerad personal och begära resurser från stat och kommun (Hasenfeld 1992). Ledningarna i organisationerna försöker därför på olika sätt tysta kritiken för att bevara deras anseende. Statusförluster riskerar att leda till minskade resurser, personalinskränkningar och/eller en rad organisatoriska problem. Repressalier mot kritiker torde ur ledningens perspektiv betraktas som ett sätt att försvara organisationens anseende, när konkurrensen om intressenter och resurser hårdnar.

\section{Slutord}

I en sådan situation och med tanke på risken för repressalier kan man förstås fråga sig varför vissa personer ändå framför kritik. Detta är en intressant och laddad fråga, inte bara för den enskilde i den konkreta situationen, utan också på samhällsnivå. I boken Gränslöst arbete-socialpsykologiska perspektiv på det nya arbetslivet analyserar Michael Allvin et al. (2006) förändringar i senmodernt arbetsliv och de psykiska och sociala konsekvenser som följer med dem. Boken bygger på ett antal fallstudier av företag och myndigheter. Man har bl.a. intervjuat konsulter, egenföretagare, systemutvecklare och frilansjournalister, alltså en något annorlunda kategori än den vi har intervjuat. Forskarna konstaterar att det nya arbetslivet fylls av människor som strävar efter självständighet, "aspirerar på autonomi«. De väljer bara arbeten som intresse- rar dem, de byter när ett bättre erbjudande dyker upp och de känner ingen lojalitet med arbetsgivaren. Kort sagt, de utnyttjar arbetet för att förverkliga sig själva (ibid. s. 95).

Forskarna hänvisar till bl.a. Giddens (1991) teorier om hur livet i det senmoderna samhället blivit ett personligt projekt för individen, och hur sandra människor, aktiviteter och institutioner väljs och utnyttjas medvetet för att befordra detta projekt» (Allvin et al. 2006 s. 95). Om arbetet inte förmår leva upp till individens förväntningar eller om arbetsvillkoren kommer i konflikt med de egna värderingarna, byter hon helt enkelt arbete. Om konflikter skulle uppstå väljer hon snarare exit än voice, ty »även om de intervjuade inte drog sig för att protestera var de inte beredda att kompromissa allt för mycket med sina krav. Den aktuella arbetsplatsen innebar inte något långsiktigt åtagande» (ibid. s. 99). Det individuella livsprojektet, den egna livskarriären i förgrunden alltså.

I det perspektivet framstår våra intervjupersoner onekligen som något otidsenliga eller avvikande. Varför väljer de voice istället för exit, trots att de därmed kanske sätter sin karriär på spel? Hur ska vi förstå deras agerande i relation till den förskjutning av fokus mot det egna personliga livsprojektet som Giddens och andra talar om? Kanske ligger det nära tillhands att tänka att dessa personer inte omfattas av denna utveckling, att de är en slags rest av en gammal pliktmoral, som innebär att man gör sin plikt såsom den definieras av traditionen eller det kollektiva.

$\AA$ andra sidan är det förstås också fullt möjligt att se deras handlingar som högst samstämmiga med den individualiserade 
arbetsmoral som råder i det nya arbetslivet. Ty om det är så att vi i högre utsträckning än tidigare kan välja de objekt vi vill identifiera oss med och engagera oss $i$, kommer vi också att ställa större krav på att dessa objekt står i samklang med våra egna värderingar (ibid.). I det perspektivet innebär därför arbetet alltid ett moraliskt övervägande, som ställs på sin spets när arbetet och dess villkor kommer i konflikt med de egna värderingarna. Det kan förvisso betyda att man håller tyst för att undvika obehag och nackdelar för den egna karriären, eller att man söker sig därifrån. Men det kan också betyda att man känner sig förpliktigad att handla av personliga, värderingsmässiga skäl, eller av etiska principer för omvårdnad, behandling eller omsorg, som har sin grund i den egna professionen eller i en politisk/ideologisk övertygelse.

\section{Referenser}

Alvesson, Mats (2001) Organisationskultur och ledning. Stockholm: Liber.

Allvin Michael, Aronsson Gunnar, Hagström Tom, Johansson Gunn \& Lundberg Ulf (2006) Gränslöst arbete-socialpsykologiska perspektiv på det nya arbetslivet. Stockholm: Liber.

Aronsson, Gunnar \& Gustafsson, Klas (1999) "Kritik eller tystnad - en studie av arbetsmarknad och anställningsförhållandens betydelse för arbetsmiljökritik". Arbetsmarknad och Arbetsliv, vol. $5 \mathrm{nr}$ 3, s. 189-206.

Becker, Howard (2006) Utanför. Avvikandets sociologi. Lund: Arkiv förlag.

Brink, Josefin et al. (2007) Stärkt yttrandeoch meddelarfrihet. Motion till riksdagen 2007:K 347.

Burleson Brant, Albrecht Terence \& Sarason Irving (1994) Communication of social support. Messages, Interactions, Relationships and Community. Thousand Oaks: Sage.

Elias, Norbert \& Scotson, John L. (1999) Etablerade och outsiders. Lund: Arkiv förlag.

Esaiasson Peter, Gilljam Mikael, Oscarsson Henrik \& Wängnerud Lena (2004) Metodpraktikan. Konsten att studera samhälle, individ och marknad. Stockholm: Norstedts Juridik.

Ekeland, Tor-Johan (2006) Konflikt och konfliktförståelse - för vården och den sociala sektorn. Stockholm: Liber.
Giddens, Antony (1991) Modernity and Self-Identity: Self ad Society in Late Modern Age. Cambridge: Polity Press.

Glazer, Myron \& Glazer, Penina (1989) The whistleblowers: Exposing corruption in government and industry. New York: Basic Books.

Goffman, Erving (1990) Stigma. Notes on the Management of Spoiled Identity. New Jersey: Penguin Books.

Hallett Tim (2003) "Symbolic Power and Organizational Culture». Sociological Theory, vol. 21 nr 2, s. 128-149.

Handler, Joel F. (1992) „Dependency and Discretion". I Yeheskel Hasenfeld (red.) Human Services as Complex Organizations. London: Sage

Hasenfeld, Yeheskel (1983) Human Service Organizations. New York: Prentice Hall.

Hasenfeld, Yeheskel (1992) "The Nature of Human Service Organizations». I Yeheskel Hasenfeld (red.) Human Services as Complex Organizations. London: Sage.

Hedin, Ulla-Carin \& Månsson, Sven-Axel (1998) Vägen ut. Om kvinnors uppbrott ur prostitutionen. Stockholm: Carlssons.

Hedin Ulla-Carin, Månsson Sven-Axel \& Tikkanen Ronny (kommande) När man måste säga ifrån: om kritik och whistleblowing i offentliga organisationer. Stockholm: Natur och Kultur (under tryckning). 
Hirschman, Albert O. (1970) Exit, voice and loyalty: Responses to decline in firms, organizations and states. Cambridge, MA: Harvard University Press.

Jasper, James M. (1997) The art of moral protest: culture, biography and creativity in social movements. Chicago: Chicago University Press.

Jordan, Thomas (2002) Konfliktkunskapens ABC. http://arbetsplatskonflikt.av.gu.se/2akad/ 22konfliktabc.html

Karasek, Robert \& Theorell, Töres (1990) Healthy work. New York: Basic Books.

King, Granville (1997) »The Effects of Interpersonal Closeness and Issue Seriousness on Blowing the Whistle». The Journal of Business Communication, vol $34 \mathrm{nr}$ 4, s. 419-436.

King, Granville (1999) "The Implications of an Organization's Structure on Whistleblowing". Journal of Business Ethics, vol. $20 \mathrm{nr}$ 4, s. 315326.

Lennéer Axelson, Barbro \& Thylefors, Ingela (2005) Arbetsgruppens psykologi. Stockholm: Natur och Kultur.

Lundquist, Lennart (2001) "Tystnadens förvaltning". I Socialstyrelsen: Utan fast punkt. Om förvaltning, kunskap, språk och etik $i$ socialt arbete. Stockholm: Socialstyrelsen.

Mesmer-Magnus, Jessica \& Viswesvaran, Chockalingam (2005) „Whistleblowing in Organizations: An Examination of Correlates of Whistleblowing Intentions, Actions and Retaliation". Journal of Business Ethics vol. $62 \mathrm{nr} 3$, s. 277297.

Miceli, Marcia \& Near, Janet (1992) Blowing the whistle. The Organizational and Legal Implications for Companies and Employees. New York: Lexington Books.

Miceli, Marcia \& Near, Janet (1994) „Relationships among value congruence, perceived victimization and retaliation against whistleblowers" Journal of Management vol. $20 \mathrm{nr}$ 4, s. 773-794. Miles, Matthew B. \& Huberman, A. Michael (1994) Qualitative Data Analysis. London: Sage.

Nader Ralph, Petkas Peter \& Blackwell Kate (1972) Whistle Blowing. New York: Grossman Publishers.

Near, Janet \& Miceli, Marcia (1995) „Effective whistle-blowing". Academy of Management Review vol. $20 \mathrm{nr}$ 3, s. 679-708.

Near Janet, Rehg Michael, van Scotter James \& Miceli Marcia (2004) Does type of wrongdoing affect the whistle-blowing process? Business Ethics Quarterly 2004, vol. 14 nr 2, s. 219-242.

O'Day Rory (1974) »Intimidation Rituals: Reactions to Reform". The Journal of Applied Behavioural Science vol. $10 \mathrm{nr}$ 3, s. 373-386.

Petersson Harry, Leppänen Vesa, Jönsson Sandra \& Tranquist Joakim (2006) Villkor i arbete med människor - en antologi om human servicearbete. Arbetsliv i omvandling 2006:4. Stockholm: Arbetslivsinstitutet.

Rehg Michael, Miceli Marcia, Near Janet \& van Scotter James (2004) „Predicting retaliation against whistle-blowers: outcomes of power relationships within organizations". Academy of Management Best Conference Paper 2004.

Vaux, Alain (1988) Social Support - Theory, Research and Intervention. New York: Praeger.

Wolfe Morrison, Elizabeth \& Milleken, Francis (2000) "Organizational silence. A barrier to change and development in a pluralistic world". The Academy of Management Review vol. 25 nr 4, s. 706-731.

Währborg, Peter (2002) Stress och den nya ohälsan Stockholm: Natur och kultur.

Ulla-Carin Hedin \& Sven-Axel Månsson: Repressalier mot kritiker... 


\section{Summary}

\section{Reprisals against critics in public organizations}

Research on whistleblowing in Sweden is scarce. In this explorative study 21 cases of whistleblowing from different human service organizations in Sweden were examined. Extensive material from thematic interviews with 28 whistleblowers, their reference persons in the workplace (usually colleagues or union representatives) and a great many documents from controlling authorities have been analysed. Most whistleblowers in the selected cases held an academic degree and had long professional careers as doctors, nurses, social workers, teachers and clergymen. The material has been analysed according to a theoretical model of the whistleblowing process from Miceli \& Near (1992): Blowing the whistle. Their definition of whistleblowing (p. 15) has also been used in the selection of cases.

Some main findings were that the organization problems motivating whistleblowing were usually cutbacks in vital services for users, unethical working methods or abuse of clients. But waste and misuse of resources, discrimination and bad working conditions could also lead to whistleblowing. Internal whistleblowing was usu- ally met with silence from supervisors and directors. The whistleblowers then went on with external whistleblowing by reporting the bad conditions to higher supervisory authorities who started thorough investigations. Their actions caused a lot of negative reactions in the organization, but they were also supported by media journalists, some experts and ordinary citizens.

In the article the retaliation processes against the whistleblowers have been described. Some of them met only mild retaliation or none at all. The majority, however, have encountered severe retaliation and different types of harassment in their organizations. Half of the interview group (15 persons) have left their positions, either on sick leave or by changing jobs. The findings show a stigmatization and marginalization process with severe consequences for the individuals. But the citied organizations usually had to change their illegal or immoral practices and benefited in the long run from the whistleblowing events. These findings are alarming and further research is needed. 